\title{
Faktor-Faktor Bauran Pemasaran yang Memengaruhi Keputusan Pembelian di Bukalapak
}

\section{Marketing Mix Factors Influencing Purchase Decision on Bukalapak}

\author{
Yohandira* \\ Sekolah Bisnis, IPB University \\ e-mail: yohandirajordan@gmail.com \\ Idqan Fahmi \\ Sekolah Bisnis, IPB University \\ e-mail: ifahmi@mb.ipb.ac.id \\ Alla Asmara \\ Departemen Ekonomi, Fakultas Ekonomi dan Manajemen, IPB University \\ e-mail: allasmara@yahoo.com
}

\begin{abstract}
The growth rate of e-commerce in Indonesia is high. The condition could be seen on the competition map between marketplaces in Indonesia. Bukalapak was one of the top three marketplaces in Indonesia that has seen the most significant decrease in visitor numbers in 2019, at 26 percent precisely. Organizations should formulate marketing strategies in accordance with marketing mix determined based on market analysis to survive in the competitive field. This research aims to analyze consumer perceptions of marketing mix and purchase decision on Bukalapak, analyze marketing mix factors that influence purchase decision on Bukalapak, and formulate marketing strategies to hold back the decline in Bukalapak visitor numbers. The research data were analyzed using Structural Equation Modeling and presented descriptively. The results showed that 66 percent of consumers rated products on Bukalapak had excellent features, 72 percent of consumers rated prices on Bukalapak were reasonable, 64 percent of consumers rated payment methods on Bukalapak were in variety, and shipping discount on Bukalapak was attractive. The marketing mix factors that significantly influenced purchase decision on Bukalapak were place and price. Recommended marketing strategies to hold back the decline in Bukalapak visitors were increasing price variations and optimizing mobile application speeds.
\end{abstract}

Keywords: bukalapak, consumer perceptions, marketing strategy, purchase decision, SEM

\begin{abstract}
ABSTRAK
Tingkat persaingan e-commerce di Indonesia tergolong tinggi. Kondisi tersebut dapat dilihat dipeta persaingan antarperon marketplace di Indonesia. Bukalapak adalah salah satu dari tiga marketplace teratas di Indonesia yang mengalami penurunan jumlah pengunjung paling signifikan pada tahun 2019, tepatnya sebesar 26 persen. Organisasi perlu memformulasikan strategi pemasaran sesuai dengan bauran pemasaran yang ditentukan berdasarkan analisis pasar untuk bertahan di lingkungan yang kompetitif. Penelitian ini bertujuan menganalisis persepsi konsumen terhadap bauran pemasaran dan keputusan pembelian di Bukalapak, menganalisis faktor-faktor bauran pemasaran yang memengaruhi keputusan pembelian di Bukalapak, dan memformulasikan strategi pemasaran untuk menahan penurunan jumlah pengunjung Bukalapak. Data penelitian dianalisis menggunakan Structural Equation Modeling dan disajikan secara deskriptif. Hasil penelitian menunjukkan bahwa sebesar 66 persen konsumen menilai produk di Bukalapak memiliki fitur yang unggul, 72 persen konsumen menilai harga di Bukalapak wajar, 64 persen konsumen menilai metode pembayaran di Bukalapak variatif, dan diskon biaya pengiriman di Bukalapak menarik. Faktor-faktor bauran pemasaran yang memengaruhi keputusan pembelian di Bukalapak adalah tempat dan harga. Strategi pemasaran yang direkomendasikan untuk menahan penurunan jumlah pengunjung Bukalapak adalah meningkatkan variasi harga dan mengoptimalkan kecepatan aplikasi seluler.
\end{abstract}

Kata Kunci: bukalapak, keputusan pembelian, persepsi konsumen, SEM, strategi pemasaran. 


\section{PENDAHULUAN}

Ekonomi internet adalah pelaku terbaru dalam sistem perekonomian negara. Google dan Temasek (2019) menjelaskan bahwa Indonesia adalah pemilik nilai ekonomi internet terbesar di Asia Tenggara dengan rata-rata pertumbuhan mencapai 49 persen per tahun. E-commerce adalah penyebab utama besarnya nilai ekonomi internet Indonesia. Adapun rata-rata pertumbuhan nilai e-commerce Indonesia adalah 88 persen setiap tahun. Saturated Sectors: Finding Gaps in The E-Commerce Market in 2020 (2020) menjelaskan bahwa Indonesia bahkan sempat dinobatkan sebagai negara dengan tingkat pertumbuhan e-commerce tertinggi di dunia pada tahun 2018. Tidak heran, tingkat persaingan marketplace di Indonesia pun tinggi. The Map of E-Commerce in Indonesia (2020) menjelaskan bahwa Bukalapak adalah salah satu dari tiga martketplace teratas di Indonesia yang mengalami penurunan jumlah pengunjung paling signifikan pada tahun 2019, tepatnya sebesar 26 persen. Mothersbaugh dan Hawkins (2016) menjelaskan bahwa organisasi memerlukan strategi pemasaran untuk bertahan di lingkungan yang kompetitif.

Strategi pemasaran adalah kombinasi semua atau sebagian faktor-faktor bauran pemasaran, yaitu produk, harga, tempat, dan promosi yang memenuhi kebutuhan konsumen. Dengan kata lain, organisasi menggunakan strategi pemasaran untuk mencapai misi operasionalnya, yakni pembelian. Pembelian adalah bagian dari proses keputusan konsumen yang terjadi setelah penentuan pilihan dan pembuatan alternatif. Konsumen biasanya menjadikan merek sebagai kriteria utama dalam membuat alternatif, sedangkan harga, saluran distribusi, dan jenis penawaran sebagai kriteria pembanding dalam menentukan pilihan. Penawaran yang menarik dapat dikatakan sebagai promosi, saluran distribusi yang terjangkau dapat dikatakan sebagai tempat, harga yang bersaing dapat dikatakan sebagai harga, dan merek yang populer dapat dikatakan sebagai produk yang diberikan oleh organisasi kepada konsumen. Maka dari itu, faktor-faktor bauran pemasaran dikatakan berpengaruh terhadap keputusan pembelian (Mothersbaugh \& Hawkins, 2016).

Basith dan Fadhilah (2018) menjelaskan bahwa produk adalah salah satu dari tiga faktor utama yang memengaruhi keputusan pembelian. Munandar et al., (2017) menjelaskan bahwa merek dengan citra tertentu memengaruhi keinginan konsumen untuk membeli sebuah produk. Kaurin et al., (2019) menjelaskan bahwa konsumen beralih dari pembelian offline ke pembelian online karena harga murah. Amanah et al., (2017) menjelaskan bahwa ketika beberapa marketplace menjual produk yang sama dengan harga yang berbeda, konsumen cenderung melakukan pembelian di marketplace yang menjual produk tersebut dengan harga paling murah. Ganapathi (2015) dan Bucko et al., (2018) menjelaskan bahwa konsumen melakukan pembelian online sebab toko online melayani pembelian selama 24 jam dan memiliki metode pembayaran yang beragam. Global Web Index (2019) menjelaskan bahwa bebas biaya pengiriman adalah promosi paling efektif untuk memengaruhi konsumen melakukan pembelian di toko online. Blackwell et al., (1994) menjelaskan bahwa konsumen melibatkan persepsi dalam membuat keputusan.

Solomon (1996) menjelaskan bahwa persepsi adalah proses psikologis yang terdiri atas menerima stimulus melalui panca indera, mengintegrasikan stimulus untuk memeroleh gambaran komprehensif mengenai sesuatu, dan menginterpretasikan stimulus. Stimulus tersebut dapat berupa informasi mengenai merek, harga, jenis penawaran, saluran distribusi, dan lainlain yang diperoleh dari sumber internal maupun sumber eksternal. Sumarwan et al., (2015) menjelaskan bahwa persepsi konsumen terhadap produk sangat memengaruhi keputusan pembelian hunian ramah lingkungan. Andrianto et al., (2013), serta Hubeis dan Titus (2016) menjelaskan bahwa semakin baik persepsi konsumen terhadap nilai pangan organik, semakin tinggi minat konsumen untuk membeli pangan organik tersebut. Dapat dikatakan bahwa Bukalapak belum merespon temuan terdahulu dengan baik. Hal tersebut dapat dilihat dari jumlah penjual di Bukalapak yang lebih sedikit dari marketplace lain. Muskita (2019) menjelaskan bahwa jumlah penjual di Bukalapak pada tahun 2019 adalah sekitar 4 juta penjual, sedangkan jumlah penjual di kompetitor pada tahun yang sama adalah sekitar 6 juta penjual. Hal tersebut menyebabkan ketersediaan produk dan harga di Bukalapak menjadi lebih terbatas. 
di kompetitor memiliki alternatif rentang harga. Padahal, alternatif rentang harga dapat membantu konsumen dalam menaksir harga produk tertentu dan menemukan produk yang sesuai dengan anggaran. Hampir seluruh alternatif filter di Bukalapak pun tidak ditampilkan, sehingga konsumen perlu melakukan banyak klik saat mencari kebutuhan. Hal tersebut menyebabkan proses pencarian kebutuhan di Bukalapak menjadi lebih lama. Selain itu, nilai subsidi biaya pengiriman di Bukalapak juga lebih kecil dari marketplace lain. Bukalapak biasanya hanya menawarkan potongan biaya pengiriman kepada konsumen bernilai kurang dari 15 ribu rupiah per transaksi, sedangkan kompetitor mampu menawarkan potongan biaya pengiriman kepada konsumen bernilai sampai dengan 20 ribu rupiah per transaksi. Keadaan tersebut diduga berdampak terhadap bagaimana konsumen melakukan pembelian di Bukalapak. Dengan demikian, tujuan penelitian ini adalah menganalisis persepsi konsumen terhadap bauran pemasaran dan keputusan pembelian di Bukalapak, menganalisis faktor-faktor bauran pemasaran yang memengaruhi keputusan pembelian di Bukalapak, dan memformulasikan strategi pemasaran untuk menahan penurunan jumlah pengunjung Bukalapak.

\section{METODE PENELITIAN}

Salah satu upaya untuk menindaklanjuti penurunan jumlah pengunjung Bukalapak adalah memformulasikan strategi pemasaran sesuai dengan bauran pemasaran yang ditentukan berdasarkan analisis pasar. Strategi tersebut digunakan untuk menarik konsumen berkunjung dan berbelanja di Bukalapak. Penelitian terdahulu menjelaskan bahwa konsumen dipengaruhi oleh faktor-faktor bauran pemasaran dan persepsi dalam melakukan pembelian. Oleh karena itu, penelitian ini bertujuan menganalisis persepsi konsumen terhadap bauran pemasaran dan keputusan pembelian di Bukalapak, menganalisis faktor-faktor bauran pemasaran yang memengaruhi keputusan pembelian di Bukalapak, dan memformulasikan strategi pemasaran untuk menahan penurunan jumlah pengunjung Bukalapak. Penelitian berjudul faktor-faktor bauran pemasaran yang memengaruhi keputusan pembelian di Bukalapak dilaksanakan di Kota Bogor.

Tabel 1. Variabel Penelitian

\begin{tabular}{|c|c|c|c|}
\hline $\begin{array}{c}\text { Variabel } \\
\text { Independen }\end{array}$ & Indikator & Skala & Referensi \\
\hline Produk & $\begin{array}{l}\text { Merek Produk } \\
\text { Fitur Produk } \\
\text { Kualitas Produk }\end{array}$ & Likert & $\begin{array}{l}\text { Kumar, } 2017 \\
\text { Singh dan Goyal, } 2009 \\
\text { Sinha dan Kim, } 2012\end{array}$ \\
\hline Hartga & $\begin{array}{l}\text { Harga Murah } \\
\text { Harga Wajar } \\
\text { Harga Kompetitif }\end{array}$ & Likert & $\begin{array}{l}\text { Suryantini et al., } 2017 \\
\text { Rizki et al., } 2019\end{array}$ \\
\hline Tempat & $\begin{array}{l}\text { Akses Toko } \\
\text { Fitur Pencarian Produk } \\
\text { Metode Pembayaran }\end{array}$ & Likert & $\begin{array}{l}\text { Ganapathi, } 2015 \\
\text { Guleviciute dan Bauboniene, } 2015 \\
\text { Syed dan Suroso, } 2018\end{array}$ \\
\hline Promosi & $\begin{array}{l}\text { Diskon Produk } \\
\text { Diskon Biaya Pengiriman } \\
\text { Bebas Biaya Pengiriman }\end{array}$ & Likert & $\begin{array}{l}\text { Baskara, } 2018 \\
\text { Ngwe dan Chen, } 2018 \\
\text { Meng dan Rong, } 2015\end{array}$ \\
\hline $\begin{array}{l}\text { Keputusan } \\
\text { Pembelian }\end{array}$ & $\begin{array}{l}\text { Membuat Pesanan } \\
\text { Menggunakan Layanan Pengiriman } \\
\text { Melakukan Pembayaran Langsung } \\
\text { Menerima Pesanan }\end{array}$ & Likert & $\begin{array}{l}\text { Mothersbaugh dan Hawkins, } 2015 \\
\text { Parmana et al., } 2019\end{array}$ \\
\hline
\end{tabular}


Penelitian kuantitatif deskriptif ini terdiri atas lima variabel, yaitu produk, harga, tempat, dan promosi sebagai variabel independen, serta keputusan pembelian sebagai variabel dependen. Ikhtisar variabel penelitian disajikan pada Tabel 1. Data penelitian diperoleh melalui wawancara konsumen menggunakan instrumen berupa kuesioner tertutup yang terdiri atas 16 indikator berupa pernyataan dan skala Likert lima tingkat gradasi positif. Penelitian ini melibatkan 128 orang konsumen yang ditentukan menggunakan Convenience Sampling Technique dengan karakteristik laki-laki dan perempuan berusia 15-64 tahun, bertempat tinggal di Jakarta, Bogor, Depok, Tangerang, atau Bekasi, dan pernah membeli produk dari ketegori produk terpopuler di Bukalapak. Adapun kategori produk yang dimaksud adalah otomotif, ponsel dan elektronik, gaya hidup dan hobi, perawatan tubuh, perlengkapan rumah tangga, dan fesyen.

Tabel 2. Kelompok Interval Indeks Persentase Indikator

\begin{tabular}{cc}
\hline Persentase Indikator $(\%)$ & Interpretasi \\
\hline $0-19,99$ & Sangat Tidak Setuju \\
$20-39,99$ & Tidak Setuju \\
$40-59,99$ & Ragu-Ragu \\
$60-79,99$ & Setuju \\
$80-100$ & Sangat Setuju \\
\hline
\end{tabular}

Persepsi konsumen terhadap bauran pemasaran dan keputusan pembelian di Bukalapak diperoleh dengan menganalisis indeks persentase indikator bauran pemasaran, di antaranya adalah merek produk, harga murah, akses toko, dan diskon produk. Nazir (2005) menjelaskan bahwa indeks persentase indikator diperoleh dari perhitungan menggunakan rumus sebagai berikut:

Indeks Persentase Indikator $=\Sigma$ Skala Likert x Jumlah Responden

$$
\text { Y X } 100
$$

$\mathrm{Y}=$ Skala Likert Tertinggi $\mathrm{x}$ Jumlah Responden Keseluruhan

Indeks persentase indikator diinterpretasikan berdasarkan kelompok interval pada Tabel 2 yang diperoleh dari perhitungan menggunakan rumus sebagai berikut:

Interval $=$ 100

Jumlah Skala Likert

Faktor-faktor bauran pemasaran yang memengaruhi keputusan pembelian di Bukalapak diperoleh dengan menguji hipotesis penelitian melalui analisis pengaruh variabel independen terhadap variabel dependen menggunakan diagram lintasan model keseluruhan sub-model ITC dari Structural Equation Modeling (SEM). Wijanto (2015) menjelaskan bahwa variabel independen dinyatakan berpengaruh signifikan terhadap variabel dependen apabila nilai t dari lintasan produk, harga, tempat, dan promosi menuju keputusan pembelian lebih dari atau sama dengan 1,96. Analisis SEM diawali dengan Confirmatory Factor Analysis (CFA) yang bertujuan mengevaluasi validitas dan reliabilitas model penelitian, serta mengevaluasi kecocokan model penelitian.

Model penelitian dinyatakan memiliki validitas yang baik apabila model tersebut terdiri atas variabel teramati (indikator) yang valid. Indikator dikatakan valid apabila nilai $t$ muatan faktor dari variabel laten (variabel) terhadap indikatornya lebih dari atau sama dengan 1,96, dan Standardized Factor Loading (SFL) dari variabel terhadap indikatornya lebih dari atau sama dengan 0,50. Model penelitian dinyatakan memiliki reliabilitas yang baik apabila model tersebut terdiri atas indikator yang reliabel. Indikator dikatakan reliabel apabila nilai Construct Reliability (CR) indikator lebih dari atau sama dengan 0,70, dan nilai Variance Extracted (VE) indikator lebih dari atau sama dengan 0,50 (Wijanto, 2015). 
Tabel 3. Standar Nilai Indikator Goodness of Fit

\begin{tabular}{cc}
\hline Indikator & Standar Nilai \\
\hline Chi-square & Nilai Kecil \\
P-value & P $>0,05$ \\
RMSEA & $\leq 0,08$ \\
NFI & $\geq 0,90$ \\
NNFI & $\geq 0,90$ \\
CFI & $\geq 0,90$ \\
IFI & $\geq 0,90$ \\
Standardized RMR & $\leq 0,05$ \\
GFI & $\geq 0,90$ \\
AGFI & $\geq 0,90$ \\
\hline
\end{tabular}

Wijanto (2015) menjelaskan bahwa model penelitian dinyatakan memiliki kecocokan yang baik apabila indikator Goodness of Fit (GOF) model tersebut memenuhi standar nilai pada Tabel 3. Strategi pemasaran untuk menahan penurunan jumlah pengunjung Bukalapak diformulasikan dengan menyesuaikan antara faktor bauran pemasaran yang berpengaruh signifikan terhadap keputusan pembelian dan persepsi konsumen terhadap indikator dari faktor tersebut. Indikator dengan indeks persentase terkecil digunakan untuk memformulasikan strategi pemasaran yang direkomendasikan guna menahan penurunan jumlah pengunjung Bukalapak. Kerangka pemikiran penelitian ini dapat dilihat pada Gambar 1.

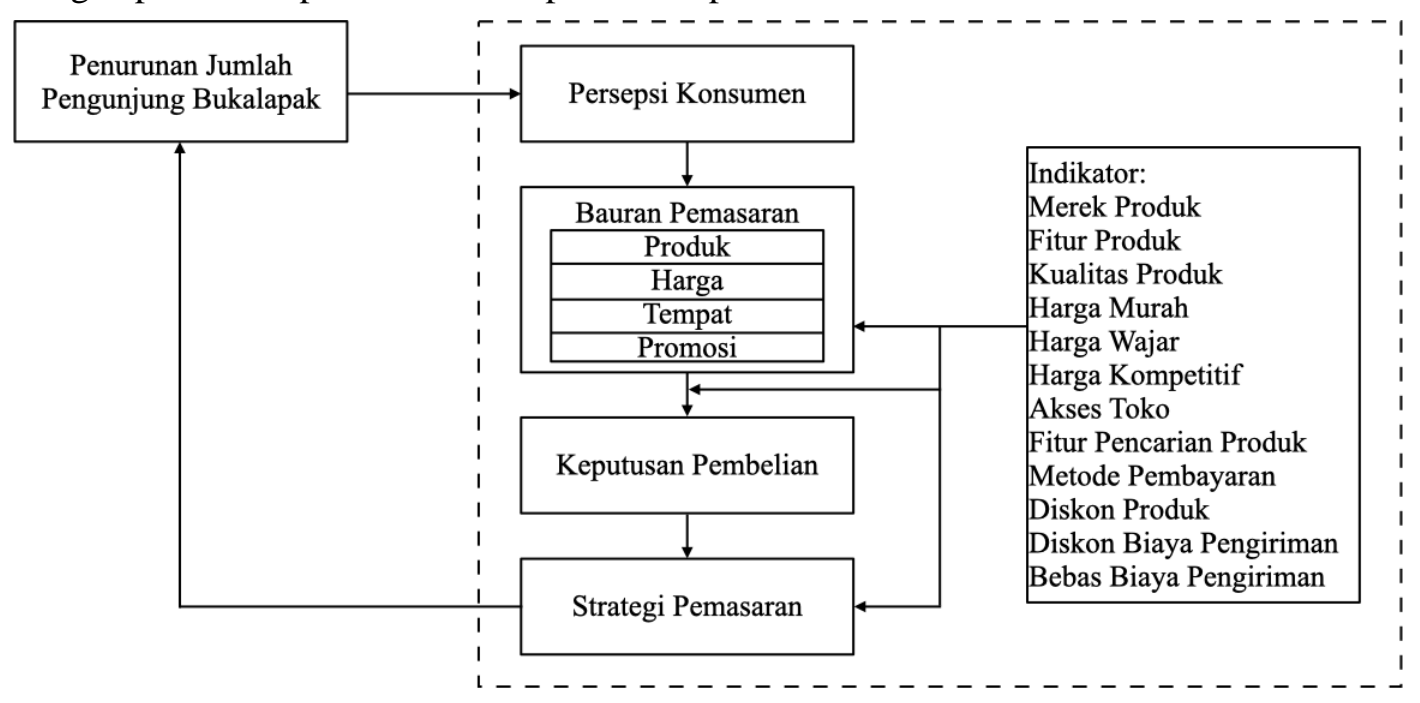

Gambar 1. Diagram Kerangka Pemikiran

Hipotesis penelitian dirumuskan berdasarkan penelitian terdahulu mengenai bauran pemasaran dan keputusan pembelian, di antaranya adalah penelitian oleh Amelia et al., (2015) yang menjelaskan bahwa faktor-faktor bauran pemasaran yang memengaruhi keputusan pembelian konsumen rental mobil adalah harga, promosi, produk, dan tempat. Azmi et al., (2015) menjelaskan bahwa produk, promosi, harga, dan tempat adalah faktor-faktor bauran pemasaran yang memengaruhi keputusan pembelian konsumen laptop. Febriana et al., (2016) menjelaskan bahwa produk, harga, promosi, dan tempat berpengaruh signifikan terhadap keputusan pembelian konsumen sepatu. Putra et al., (2020) menjelaskan bahwa produk, harga, promosi, dan tempat berpengaruh signifikan terhadap keputusan pembelian konsumen hotel. Oleh sebab itu, hipotesis penelitian ini adalah sebagai berikut: 


\section{HASIL DAN PEMBAHASAN}

Persepsi Konsumen terhadap Bauran Pemasaran dan Keputusan Pembelian di Bukalapak Persepsi konsumen terhadap indikator bauran pemasaran tidak lepas dari pengalaman konsumen dalam melakukan pembelian di toko online, khususnya Bukalapak. Persepsi tersebut direpresentasikan oleh indeks persentase indikator bauran pemasaran. Berdasarkan Tabel 4, indeks persentase merek produk, diskon produk, bebas biaya pengiriman, diskon biaya pengiriman, dan harga murah termasuk dalam kelompok interval indeks persentase 60-79,9 persen. Indeks persentase fitur produk, kualitas produk, akses toko, harga kompetitif, harga wajar, fitur pencarian produk, dan metode pembayaran termasuk dalam kelompok interval indeks persentase 80-100 persen. Hal tersebut menandakan bahwa konsumen menyetujui pernyataan mengenai popularitas merek, penggunaan diskon produk, penggunaan bebas biaya pengiriman, penggunaan diskon biaya pengiriman, dan harga murah.

Konsumen sangat menyetujui pernyataan terkait keunggulan produk, kualitas produk, aksesibilitas marketplace, harga kompetitif, harga wajar, kepraktisan fitur pencarian produk, dan variasi metode pembayaran. Interpretasi indeks persentase indikator bauran pemasaran menjelaskan bahwa persepsi konsumen terhadap bauran pemasaran dan keputusan pembelian di Bukalapak adalah produk di Bukalapak lebih utama dalam hal kualitas dan fitur daripada merek. Harga di Bukalapak bernilai wajar dan kompetitif, meskipun tidak begitu murah. Bukalapak adalah marketplace yang mampu melayani pembayaran melalui metode yang beranekaragam, memiliki fitur pencarian produk yang dapat memermudah proses pencarian kebutuhan, dan dapat diakses 24 jam khususnya melalui aplikasi seluler. Bukalapak juga menawarkan berbagai promosi menarik, namun yang paling menarik bagi konsumen adalah diskon biaya pengiriman menawarkan berbagai promosi menarik, namun yang paling menarik bagi konsumen adalah diskon biaya pengiriman.

Tabel 4. Persepsi Konsumen terhadap Indikator Bauran Pemasaran

\begin{tabular}{lcl}
\hline Indikator & Indeks $(\%)$ & Kesimpulan \\
\hline Merek Produk & 74,53 & Populer \\
Fitur Produk & 80,15 & Unggul \\
Kualitas Produk & 80,62 & Baik \\
Harga Murah & 78,90 & Murah \\
Harga Wajar & 82,65 & Wajar \\
Harga Kompetitif & 82,50 & Kompetitif \\
Akses Toko & 82,18 & Terjangkau \\
Fitur Pencarian Produk & 82,96 & Praktis \\
Metode Pembayaran & 83,90 & Variatif \\
Diskon Produk & 75,62 & Menarik \\
Diskon Biaya Pengiriman & 78,75 & Menarik \\
Bebas Biaya Pengiriman & 77,81 & Menarik \\
\hline
\end{tabular}

Faktor-Faktor Bauran Pemasaran yang Memengaruhi Keputusan Pembelian di Bukalapak

Confirmatory Factor Analysis

Berdasarkan Tabel 5, nilai t muatan faktor dari produk terhadap PRD1, PRD2, dan PRD3 lebih dari 1,96. Begitu juga nilai t muatan faktor dari harga, tempat, promosi, dan keputusan pembelian terhadap indikator masing-masing. SFL dari produk terhadap PRD1, PRD2, dan PRD3 lebih dari 0,50. Begitu pula SFL dari harga, tempat, promosi, dan keputusan pembelian terhadap indikator masing-masing. Hal tersebut menunjukkan bahwa model terdiri atas indikator yang valid. 
Tabel 5. Validitas dan Reliabilitas Model Penelitian

\begin{tabular}{|c|c|c|c|c|c|c|}
\hline \multirow{2}{*}{ Variabel } & \multirow{2}{*}{ Indikator } & \multicolumn{2}{|c|}{ Validitas } & \multicolumn{2}{|c|}{ Reliabilitas } & \multirow[t]{2}{*}{ Kesimpulan } \\
\hline & & Nilai t & SFL & $\mathrm{CR}$ & VE & \\
\hline \multirow[t]{3}{*}{ Produk } & PRD1 & 6,91 & 0,58 & & & \\
\hline & PRD2 & 12,49 & 0,93 & 0,85 & 0,67 & Valid dan Reliabel \\
\hline & PRD3 & 11,76 & 0,89 & & & \\
\hline \multirow[t]{3}{*}{ Harga } & $\mathrm{PRC} 2$ & 7,36 & 0,63 & & & \\
\hline & PRC3 & 13,41 & 0,92 & 0,75 & 0,62 & Valid dan Reliabel \\
\hline & PLC1 & 7,08 & 0,63 & & & \\
\hline \multirow[t]{3}{*}{ Tempat } & PLC2 & 9,31 & 0,79 & & & \\
\hline & PLC3 & 8,59 & 0,74 & 0,76 & 0,52 & Valid dan Reliabel \\
\hline & PRM1 & 11,52 & 0,85 & & & \\
\hline \multirow[t]{2}{*}{ Promosi } & PRM2 & 11,55 & 0,85 & 0,90 & 0,75 & Valid dan Reliabel \\
\hline & PRM3 & 12,74 & 0,91 & & & \\
\hline $\begin{array}{l}\text { Keputusan } \\
\text { Pembelian }\end{array}$ & PCS4 & 15,38 & 0,98 & 0,96 & 0,96 & Valid dan Reliabel \\
\hline
\end{tabular}

Model pun terdiri atas indikator yang reliabel. Hal tersebut ditunjukkan oleh nilai CR indikator produk, indikator harga, indikator tempat, indikator promosi, dan indikator keputusan pembelian yang lebih dari 0,70 , serta nilai VE indikator produk, indikator harga, indikator tempat, indikator promosi, dan indikator keputusan pembelian yang lebih dari 0,50. Berdasarkan Tabel 6, semua indikator GOF memenuhi standar nilai tingkat kecocokan baik, kecuali Adjusted Goodness of Fit Index (AGFI). Dengan demikian, model penelitian ini dinyatakan memiliki validitas, reliabilitas, dan kecocokan yang baik.

\begin{tabular}{cccc} 
Tabel 6. Kecocokan Model Penelitian & & & \\
\hline IndikatorGOF & Standar Nilai & Hasil & Kecocokan \\
\hline Chi-Square & Nilai Kecil & 56,99 & \\
P-value & P>0,05 & 0,11 & Baik \\
RMSEA & $<0,08$ & 0,04 & Baik \\
NFI & $>0,90$ & 0,94 & Baik \\
NNFI & $>0,90$ & 0,98 & Baik \\
CFI & $>0,90$ & 0,98 & Baik \\
IFI & $>0,90$ & 0,98 & Baik \\
Standardized RMR & 0,05 & 0,05 & Baik \\
GFI & $>0,90$ & 0,93 & Baik \\
AGFI & $>0,80<0,90$ & 0,88 & Kurang Baik \\
\hline
\end{tabular}


Analisis Pengaruh Produk, Harga, Tempat, dan Promosi terhadap Keputusan Pembelian

Berdasarkan Gambar 2, nilai t dari lintasan produk dan promosi menuju keputusan pembelian kurang dari 1,96 (-1,77 dan -1,08). Hal tersebut menjelaskan bahwa produk dan promosi tidak berpengaruh signifikan terhadap keputusan pembelian, sehingga $\mathrm{H} 1$ dan $\mathrm{H} 4$ ditolak. Di sisi lain, nilai t dari lintasan harga dan tempat menuju keputusan pembelian lebih dari 1,96 (4,05 dan 4,13). Hal tersebut menjelaskan bahwa harga dan tempat berpengaruh signifikan terhadap keputusan pembelian, sehingga $\mathrm{H} 2$ dan $\mathrm{H} 3$ diterima. Artinya, faktor-faktor bauran pemasaran yang memengaruhi keputusan pembelian di Bukalapak adalah harga dan tempat.

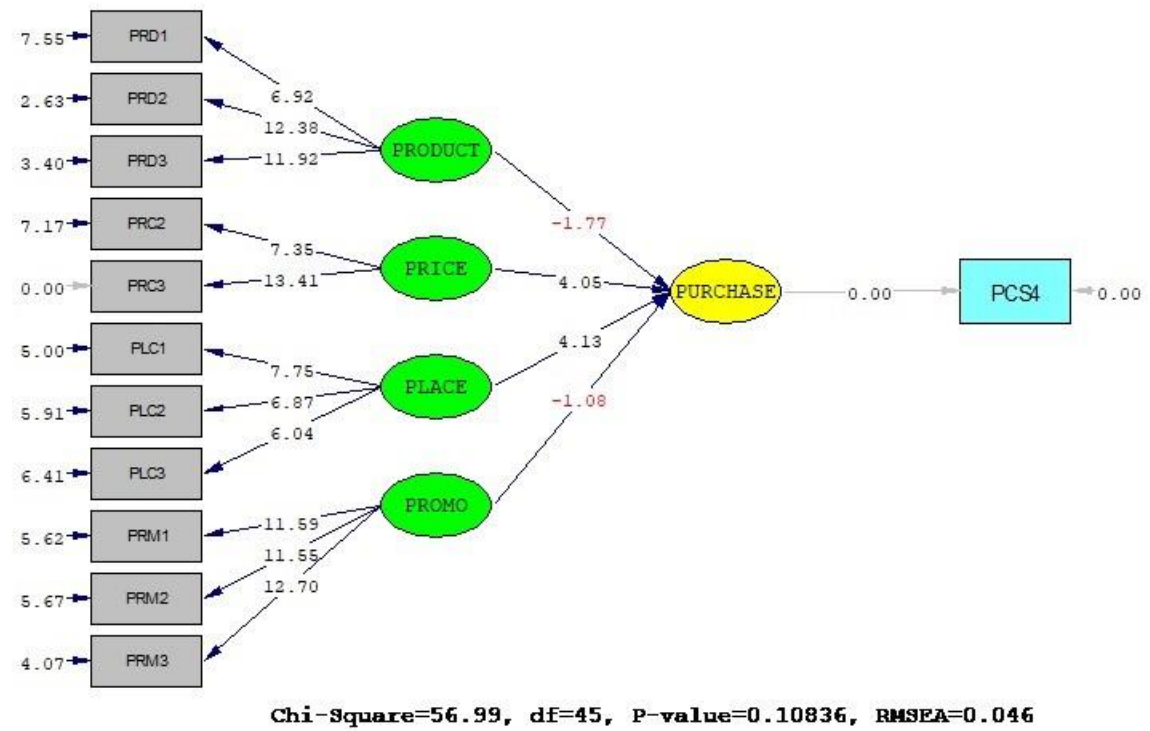

Gambar 3. Diagram Lintasan Model Keseluruhan Sub-model ITC (T-value)

Tempat yang direfleksikan oleh akses toko, fitur pencarian produk, dan metode pembayaran berpengaruh signifikan terhadap keputusan pembelian karena berdasarkan Ganapathi (2015) dan Bucko et al., (2018) konsumen hendak memeroleh manfaat praktis (transaksi instan) yang tidak dapat diperoleh di toko offline, seperti toko online dapat diakses 24 jam, fitur pencarian produk dapat memermudah proses pencarian kebutuhan, dan pembayaran dapat dilakukan melalui metode yang beranekaragam. Harga yang direfleksikan oleh harga kompetitif dan harga wajar juga berpengaruh signifikan terhadap keputusan pembelian sebab berdasarkan Deloitte Touche Tohmatsu (2019) konsumen online di Indonesia lebih mementingkan kompetitivitas harga dalam melakukan pembelian. Konsumen pun memiliki kecenderungan untuk menyesuaikan antara harga dan kondisi produk dalam melakukan pembelian (Carpenter dan Chernev, 2001).

Promosi yang direfleksikan oleh bebas biaya pengiriman, diskon produk, dan diskon biaya pengiriman tidak berpengaruh signifikan terhadap keputusan pembelian karena berdasarkan Firdausy dan Idawati (2017), serta Amanah dan Harahap (2018) konsumen lebih mementingkan hal lain dalam melakukan pembelian di toko online, khususnya layanan pasca pembelian. Klynveld Peat Marwick Goerdeler (2017) menjelaskan bahwa salah satu faktor pendorong konsumen melakukan pembelian online adalah penawaran lebih menarik. Contohnya adalah bebas biaya pengiriman yang dinyatakan sebagai jenis penawaran terfavorit bagi konsumen online. Penawaran tersebut bahkan berpotensi menyebabkan konsumen menambah item ke keranjang belanja. Konsumen memang memeroleh manfaat dari promosi yang ditawarkan oleh toko online, tetapi manfaat tersebut tidak sebanding dengan resiko yang dihadapi oleh konsumen saat melakukan pembelian di toko online.

Produk yang direfleksikan oleh fitur produk, kualitas produk, dan merek produk pun tidak berpengaruh signifikan terhadap keputusan pembelian sebab berdasarkan Teguh dan Wijaya (2012), serta Ariansyah et al., (2020) konsumen tidak dapat melihat produk secara langsung, sehingga konsumen tidak mengetahui kondisi produk yang sebenarnya. Konsumen dapat 
menemukan berbagai merek nasional dan Internasional di toko online, namun bukan berarti semua merek tersebut populer dimata konsumen. Tidak jarang merek yang dipasarkan secara online adalah merek baru, mengingat salah tujuan pengembangan platform bisnis berbasis digital adalah mendorong masyarakat untuk melakukan usaha mandiri, khususnya Usaha Mikro, Kecil, dan Menengah (UMKM). Dalam konteks online, konsumen biasanya menilai produk berdasarkan gambar, deskripsi, dan ulasan dalam membuat keputusan (Klynveld Peat Marwick Goerdeler, 2017).

\section{Strategi Pemasaran untuk Menahan Penurunan Jumlah Pengunjung Bukalapak}

Tempat merupakan faktor bauran pemasaran yang berpengaruh paling signifikan terhadap keputusan pembelian. Persepsi konsumen terhadap indikator tempat, yaitu akses toko, fitur pencarian produk, dan metode pembayaran menunjukkan bahwa persepsi konsumen terhadap Bukalapak sebagai tempat adalah Bukalapak merupakan marketplace yang mampu melayani pembayaran melalui metode yang beranekaragam, memiliki fitur pencarian produk yang dapat memermudah proses pencarian kebutuhan, dan dapat diakses 24 jam khususnya melalui aplikasi seluler. Harga merupakan faktor bauran pemasaran lainnya yang berpengaruh signifikan terhadap keputusan pembelian. Persepsi konsumen terhadap indikator harga, yaitu harga murah, harga wajar, dan harga kompetitif menunjukkan bahwa persepsi konsumen terhadap harga di Bukalapak adalah benilai wajar dan kompetitif, walaupun tidak begitu murah. Padahal, salah satu hal yang dipertimbangkan oleh konsumen dalam melakukan pembelian online adalah perbedaan harga. Jumlah penjual di Bukalapak pada tahun 2019 memang lebih sedikit dari kompetitor, sehingga variasi harga di Bukalapak menjadi terbatas. Hal tersebut mengakibatkan konsumen kekurangan alternatif dalam melakukan pembelian di Bukalapak.

Berdasarkan uraian tersebut, strategi pemasaran yang direkomendasikan untuk menahan penurunan jumlah pengunjung Bukalapak adalah meningkatkan variasi harga dengan memromosikan Bukalapak sebagai platform bisnis berbasis digital yang unggul kepada parapelaku usaha, khususnya UMKM untuk menambah saluran distribusi guna memerluas target pasar. Peningkatan jumlah penjual di Bukalapak dapat menambah alternatif harga di Bukalapak. Hal tersebut dapat memotivasi konsumen untuk berkunjung dan berbelanja di Bukalapak. Di samping itu, strategi pemasaran lainnya untuk menahan penurunan jumlah pengunjung Bukalapak adalah mengoptimalkan kecepatan aplikasi seluler. Deloitte Touche Tohmatsu (2020) menjelaskan bahwa meningkatkan kecepatan aplikasi seluler 0.1 detik dapat menurunkan bounce rate dan meningkatkan tingat konversi sebesar 8 persen. Hal tersebut dapat dilakukan dengan menyederhanakan bahasa program dan menghapus kode yang tidak diperlukan, meletakkan logo memuat gambar di luar layar (load images offscreen), menyesuaikan dimensi gambar dengan ukuran layar, dan mengelola kecepatan secara rutin.

\section{Implikasi Manajerial}

Tempat adalah faktor bauran pemasaran yang memengaruhi konsumen melakukan pembelian di Bukalapak. Konsumen berpendapat bahwa Bukalapak adalah marketplace yang memiliki metode pembayaran yang variatif dan fitur pencarian yang praktis, serta dapat dijangkau kapan pun dan di mana pun. Temuan tersebut dapat menjadi masukkan bagi manajemen Bukalapak dalam membuat keputusan mengenai pengelolaan situs web dan aplikasi seluler untuk meningkatkan pengalaman pengguna (user experience). Contohnya adalah Bukalapak dapat merancang fitur "Terakhir Diklik" yang berfungsi sebagai daftar produk yang pernah dilihat dan diminati oleh konsumen, namun terlewat untuk dimasukkan ke halaman favorit (wishlist). Bukalapak juga dapat membuat aplikasi seluler khusus penjual. Aplikasi tersebut dapat memisahkan antara aktivitas pengelolaan toko dan pembelian, sehingga kecepatan aplikasi seluler Bukalapak berpotensi menjadi lebih cepat. Harga pun adalah faktor bauran pemasaran yang memengaruhi konsumen melakukan pembelian di Bukalapak. Konsumen berpendapat bahwa harga di Bukalapak bernilai wajar, kompetitif, dan murah. Temuan tersebut dapat menjadi masukkan bagi manajemen Bukalapak dalam membuat keputusan terkait pengelolaan harga pasar. Bukalapak dapat mengadopsi fitur "Price Tracker" untuk menjaga sportivitas persaingan antarpenjual. Jika terdapat penjual yang menjual produk dengan harga terlalu tinggi atau terlalu rendah, maka Bukalapak dapat mengirimkan imbauan penyesuaian harga kepada penjual melalui fitur pesan, notifikasi, atau e-mail. 


\section{KESIMPULAN}

Berdasarkan analisis persepsi konsumen terhadap bauran pemasaran dan keputusan pembelian di Bukalapak, serta analisis faktor-faktor bauran pemasaran yang memengaruhi keputusan pembelian di Bukalapak, hasil penelitian ini dapat disimpulkan sebagai berikut: (1) Persepsi konsumen terhadap bauran pemasaran dan keputusan pembelian di Bukalapak adalah produk di Bukalapak lebih utama dalam hal kualitas dan fitur daripada merek. Harga di Bukalapak bernilai wajar dan kompetitif, meskipun tidak begitu murah. Bukalapak adalah marketplace yang mampu melayani pembayaran melalui metode yang beranekaragam, memiliki fitur pencarian produk yang dapat memermudah proses pencarian kebutuhan, dan dapat diakses 24 jam khususnya melalui aplikasi seluler. Bukalapak juga menawarkan berbagai promosi menarik, namun yang paling menarik bagi konsumen adalah diskon biaya pengiriman. (2) Faktor-faktor bauran pemasaran yang memengaruhi keputusan pembelian di Bukalapak adalah tempat dan harga. (3) Strategi pemasaran yang direkomendasikan untuk menahan penurunan jumlah pengunjung Bukalapak adalah meningkatkan variasi harga guna memotivasi konsumen berkunjung dan berbelanja di Bukalapak. Strategi pemasaran lainnya untuk menahan penurunan jumlah pengunjung Bukalapak adalah mengoptimalkan kecepatan aplikasi seluler guna menurunkan bounce rate dan meningkatkan tingat konversi di Bukalapak.

\section{DAFTAR PUSTAKA}

Amanah, D., Gaffar, V., Harahap, D. A., Hurriyati, R., \& Wibowo, L. A. (2017). Perilaku Store Switching dalam Berbelanja Online. Forum Manajemen Indonesia, 9, 1-9. 10.17605/OSF.IO/82JHV.

Amanah, D., \& Harahap, D. A. (2018). Examining The Effect of Product Assortment and Price

Discount toward Online Purchase Decision of University Student in Indonesia. Jurnal Manajemen dan Kewirausahaan, 20(2): 99-104. https://doi.org/10.9744/jmk.20.2.99104.

Amelia, L. R., Kusumawati, A., \& Mawardi M. K. (2015). The Influence of Marketing Mix Variables on Purchase Decision and Customer Satisfaction (Case Study of Customer of Vitiara Rent Car Malang). Jurnal Administrasi Bisnis, 28(2), 1-10.

Andrianto, M. S., Munandar, J. M., \& Rizki, D. A. (2013). Analisis Persepsi Konsumen dan Strategi Pemasaran Beras Analog (Analog Rice). Jurnal Manajemen dan Organisasi, 4(2), 145-162. https://doi.org/10.29244/jmo.v4i2.12621.

Azmi M. F., Suharyono, \& Sunarti. (2015). Pengaruh Bauran Pemasaran terhadap Keputusan Pembelian (Survei pada Mahasiswa yang Menggunakan Notebook Asus di Universitas Brawijaya. Jurnal Administrasi Bisnis, 28 (1), 175-184.

Ariansyah, Munandar, J. M., Najib, M. (2020). Faktor-Faktor yang Memengaruhi Niat Konsumen untuk Membeli Produk Melalui E-Commerce, 11(2), 83-90. https://doi.org/10.29244/jmo.v11i2.32170.

Basith, A., \& Fadhilah, F. (2018). Analisis Faktor-Faktor yang Memengaruhi Keputusan Pembelian Produk McDonald's di Jatiasih Bekasi. Jurnal Manajemen dan Organisasi, 9(3), 191-202. https://doi.org/10.29244/jmo.v9i3.28224.

Baskara, I. B. (2018). Pengaruh Potongan Harga (Discount) terhadap Pembelian Tidak Terencana (Impluse Buying) (Studi pada Pengunjung Matahari Department Store Johar Plaza Jember). Jurnal Manajemen Bisnis, 5(2), 87-96. https://doi.org/10.22219/jmb.v5i2.5382.

Bauboniene, Z., \& Guleviciute, G. (2015). E-Commerce Factors Influencing Consumers Online Shopping Decision. Journal of Social Techonologies, 5(1), 74-81. 10.13165/ST-15-5-106.

Blackwell, R. D., Engel, J. F., \& Miniard, P. W. (1994). Perilaku Konsumen. Jilid ke-1. Jakarta: Bina Rupa Aksara.

Bucko, J., Ferencova, M., \& Kakalejcik, L. (2018). Online Shopping: Factors that Affect Consumer Purchasing Behavior. Cogent Business and Management, 5(1), 1-15. https://doi.org/10.1080/23311975.2018.1535751.

Jurnal Manajemen dan Organisasi (JMO), Vol. 12 No. 2 , Agustus 2021, Agustus 2021 ,
Hal. $122-133$ 
Carpenter, G. S., \& Chernev, A. (2001). The Role of Market Efficiency Intuitions in Consumer Choice: A Case of Compensatory Inferences. Journal of Marketing Research, 38(3): 349361. https://doi.org/10.1509/jmkr.38.3.349.18865.

Chen, C., \& Ngwe, D. (2018). Shipping Fees and Product Assortment in Online Retail. Harvard Business School, 19(34), 2-39.

Deloitte Touche Tohmatsu. (2019). Have Indonesians' Patterns Shifted towards Digital?. Retrieved from https://www2.deloitte.com/content/dam/Deloitte/id/Documents/aboutdeloitte/id-about-dip-edition-1-chapter-5-en-sep2019.pdf.

Deloitte Touche Tohmatsu. (2020). Milliseconds make Millions. Retrieved from https://www2.deloitte.com/content/dam/Deloitte/ie/Documents/Consulting/Milliseconds_ Make_Millions_report.pdf.

Devita, L. D. R., Hidayat, K., \& Rizki, A. G. (2019). Pengaruh Citra Merek dan Harga terhadap Keputusan Pembelian pada E-Commerce Shopee Indonesia (Survei pada Mahasiswa S1 Fakultas Ilmu Administrasi Universitas Brawijaya Angkatan 2015/2016 dan 2016/2017 yang Membeli Barang Secara Online di E-Commerce. Jurnal Administrasi Bisnis, 72(2), 49-56.

Fahmi, I., Nurrohmat, D. R., \& Parmana. (2019). The Influence of Marketing Mix Factors in Purchasing Decision for Wooden Furniture Case of Furnimart Bogor. Indonesian Journal of Business and Entrepreneurship, 5(1), 54-64. https://doi.org/10.17358/ijbe.5.1.54.

Febriana, M. B., Sunarti, \& Yulianto, E. (2016). Pengaruh Bauran Pemasaran terhadap Keputusan Pembelian (Survei kepada Konsumen Sepatu Merek Converse di Kota Malang). Jurnal Administrasi Bisnis, 32(2), 33-38.

Firdausy, C. M., \& Idawati, R. (2017). Effects of Service Quality, Price, and Promotion on Customers' Purchase Decision of Traveloka Online Airline Tickets in Jakarta, Indonesia. International Journal of Management Science and Business Administration, 3(2), 42-49. https://dx.doi.org/10.18775/ijmsba.1849-5664-5419.2014.32.1004.

Ganapathi, R. (2015). A Study on Factors Affecting Online Shopping Behavior of Consumers in Chennai. Journal of Management Research and Analysis, 2(2), 123-126.

Global Web Index. (2019). Commerce Globalwebindex's Flagship Report on The Latest Trends in Online Commerce.

Google dan Temasek. (2019). E-Conomy SEA Spotlight 2019 Swipe Up and to The Right: Southeast Asia's \$100 Billion Internet Economy.

Goyal, B. B., \& Singh, J. (2009). Mobile Handset Buying Behavior of Different Age and Gender Groups. International Journal of Business and Management, 4(5), 179-187. https://doi.org/10.5539/IJBM.V4N5P179.

Hartono, S., Rahmaningtyas, A., \& Suryantini, A. (2017). Factors Affecting Online Purchasing of Local Food. Jurnal Agro Ekonomi, 28(2), 189-204. https://doi.org/10.22146/jae.26129.

Hubeis, M., \& Titus, B. R. (2016). Analisis Persepsi Nilai, Kepedulian Keamanan Pangan dan Kesadaran Kesehatan yang Memengaruhi Keinginan Membeli Pangan Organik. Jurnal Manajemen dan Organisasi, 7(1): 73-82. https://doi.org/10.29244/jmo.v7i1.14072.

Mothersbaugh, D. L., \& Hawkins, D. I. (2016). Consumer Behavior Building Marketing Strategy. New York: McGraw Hill Education.

Muskita, P. (2019). Bukalapak Claims It's on Track for \$5b in GMV for 2019. Techinasia. Retrieved Maret 23, 2021, from https://www.techinasia.com/bukalapak.-claims-track-5bgmv-2019.

Kaurin, T., Kilibarda, M., \& Vasic, N. (2019). The Influence of Online Shopping Determinants on Customer Satisfaction in the Serbian Market. Journal of Theoretical and Applied Electronic Commerce Research, 14(2), 70-89. https://dx.doi.org/10.4067/S071818762019000200107.

Jurnal Manajemen dan Organisasi

(JMO),

Vol. 12 No. 2 ,

Agustus 2021,

Kumar, A. (2017). Factors Determinant Buying Behavior of Students: In Online Context. International Journal of Research in Management, Economics, and Commerce, 7(12), 61-64.

Kim, J., \& Sinha, J. (2012). Factors Affecting Indian Consumer 'Online Buying Behavior. Innovative Marketing, 8(2), 46-57. 
Klynveld Peat Marwick Goerdeler. (2017). The Truth about Online Consumers 2017 Global Online Consumer Report. Retreived from https://assets.kpmg/content/dam/kpmg/xx/pdf/2017/01/the-truth-about-onlineconsumers.pdf.

Meng, Q., Rong, X., \& Wan, X. (2015). A Robust Ordering Strategy for Retailers Facing A Free Shipping Option, Plos One, 10(5), 1-14. https://doi.org/10.1371/journal.pone.0125939.

Saturated Sectors: Finding Gaps in The E-Commerce Market in 2020. (2019, March 25). Merchant Machine. Retrieved April 7, 2021 from https://merchantmachine.co.uk/saturated-sectors/.

Munandar, J. M., Nurhasanah, S., \& Syamsun, M. (2017). Faktor-Faktor yang Memengaruhi Minat Beli Produk Makanan Olahan Halal pada Konsumen. Jurnal Manajemen dan Organisasi, 8(3): 251-260. https://doi.org/10.29244/jmo.v8i3.22473.

Nazir, M. (2005). Metode Penelitian. Bogor: Ghalia Indonesia.

Putra, Q. E., Singh, S. K., Sitepu, R. B., \& Tarigan, Z. J. H. (2020). The Impact of Marketing Mix on The Consumer Purchase Decision in The Surabaya-Indonesia Hotel Residence. SHS Web of Conferences, 76, 1-8. https://doi.org/10.1051/shsconf/20207601038.

Sumarwan, U., Wardhani, W., \& Yuliati, L. N. (2015). Pengaruh Persepsi dan Preferensi Konsumen terhadap Pembelian Hunian Green Marketing. Jurnal Manajemen dan Organisasi, 6(1), 45-63. https://doi.org/10.29244/jmo.v6i1.12183.

Solomon, M. R. (1996). Consumer Behavior. New Jersey: Prentice Hall International.

Suroso, J. S., \& Syed, A. A. (2018). Factors Affecting Consumers' Decision for E-Hotel Booking. Communication and Information Technology Journal, 12(2), 111-123. https://doi.org/10.21512/commit.v12i2.4917.

Teguh, C., \& Wijaya, P. S. M. (2012). Faktor-Faktor yang Memengaruhi Minat Beli di Online Shop Specialis Guess. Jurnal Riset Manajemen dan Bisnis, 7(2), 147-160.

The Map of E-Commerce in Indonesia. (2020, February 5). Iprice. Retrieved February 5, 2020, from: https://iprice.co.id/insights/mapofecommerce/en/.

Wijanto, S. H. (2015). Metode Penelitian Menggunakan Structural Equation Modeling dengan Lisrel 9. Jakarta: Lembaga Penerbit Fakultas Ekonomi Universitas Indonesia. 